\title{
Understanding contemporary Family Support: Reflections on theoretical and conceptual frameworks
}

\author{
David Herrera-Pastor ${ }^{1}$, Nick Frost ${ }^{2}$, and Carmel Devaney ${ }^{3}$
}

\begin{abstract}
Family Support is a transdisciplinary field made up of practices and knowledge from different areas, theories and approaches. This article strives to contribute to the development of this complex epistemological foundation by undertaking a review of the main theoretical frameworks. The relationship between the practice and theory of Family Support is analysed in the paper. A review of the 'state of the art' is undertaken, exploring both the role of wide-ranging social theory, and more specific psycho-social theories. Practical examples are provided to ground the analysis. Finally, the article proposes an integrated model proposed providing a critical and versatile approach to understanding different realities. Cross-national joint construction is encouraged to advance Family Support as both a theory and to provide a framework which guides both practice and policy.
\end{abstract}

Keywords: Family Support; epistemological foundation; research; practice; policy; integrated model.

1. Senior researcher, Faculty of Education \& Sport, University of Granada, Melilla, Spain

2. Professor, School of Health and Community Studies, Leeds Beckett University, UK

3. Lecturer, UNESCO Child and Family Research Centre, National University of Ireland, Galway

Address for correspondence: dherrera@ugr.es

Date of first (onliine) publication: 


\section{Introduction}

This article makes the case for a theoretical and conceptual under-pinning for Family Support as a social practice. The work has emerged from our cross-national collaboration as part of the European Family Support Network (ESFN), 'a network that is a champion family support research, theory, policy and practice development across Europe' (EFSN, 2020). The three authors have a strong commitment to family support policy and practice - we also agree that currently the underpinning theoretical base is under-developed and work is required at this level if family support is to become mainstream and sustainable.

We provide an overview of the role of theory in informing social practices before exploring the current state of the art. We then outline wide-ranging social theory and more micro-level psycho-social theory as both having a role in relation to family support. We then propose an integrated model which has been accepted as an approach by the ESFN.

\section{Theory and practice in Family Support: An overview}

It is tempting to dismiss social theories as irrelevant, or at best marginal, to professional practice. However, there is now an accepted understanding of formal Family Support as an approach to practice in services working with, and on behalf of children, young people and their families. It is generally agreed that all disciplines who work with children, regardless of the remit of their service, the specifics of their role and their original training, can incorporate a Family Support approach into their practice. Formal Family Support as a practice is underpinned by a strong value base, an a number of social science theories and a set of research-based guiding principles with the essence of Family Support captured in its mode of delivery.

We wish to argue here that theory is central and essential in developing sound and coherent family support knowledge and practice - in fact, one of the struggles in establishing family support as a dominant form of practice has been a lack of explicit clarification about its coherent theoretical base.

A prime example of how theory can transform practice comes from the English example of the organised sexual abuse of young people by street-based gangs. At the turn of this century, in the early 2000s, such an activity was referred to as 'child prostitution'. This conceptualisation had profound implications for practice: the young people were seen as criminals, who had made what was often referred to as making a 'life-style choice'. The young people were regarded as troublesome by the authorities: the perpetrators were regarded as being 'punters' or 'pimps' to whom the authorities paid little attention. From around 2006 the phrase 'child sexual exploitation' (CSE) came into play: the adoption of this concept transformed 
practice (Firmin, Warrington and Pearce, 2016). Young people became seen as being the victims of organised forms of exploitation: the perpetrators were perceived, and eventually prosecuted, as criminals. Thus a concept, based on social theory, totally transformed professional practice. This may be a dramatic example but it illustrates how theory can inform, and indeed transform, practice.

In this article we argue and try to clarify that family support, as a trans-disciplinary sphere of intervention, among others, is formed by two fields of theory: one drawing on what we identify as 'social structural' approaches - informed by concepts such as social exclusion, inequality and poverty (Bywaters, 2013). The other field draws more on theories relating to social psychology and social problems: we will identify this as 'psycho-social' theory, attempting to explain issues such as domestic abuse, substance abuse and family conflict. Whilst these can be viewed in social structural terms, such global theories find it hard to explain why a particular household may experience various social problems, whilst others will not. Social structural theory does not always provide practice guidance for the individual practitioner working with a particular family.

We explore both of these forms of theory in turn: social structural theory and psycho-social theory. We then put the forward the case for what could be described as integrated, or perhaps pragmatic, but which attempts to link big social structural issues with the manifestation of these factors on particular households. Inter-sectionality is a useful idea here which brings together the impact of forms of difference (social class, gender, (dis)ability and sexuality) into a coherent set of ideas.

The utilisation of theory is essential to the future of family support - it can inform professional education, research, networking, policy and practice development. This article makes the case for a coherent theory - which has already informed the development of the European Family Support Network. We go on to argue for an eclectic, pragmatic but nevertheless coherent utilisation of theory to inform the way forward for family support. To underpin this we reflect first of all on the current state of art in family support.

\section{Family support: The current state of the art}

\section{Partnership/Co-production}

Working collaboratively with families to whatever extent possible is a core principle of a Family Support orientation. In practice, family can be viewed as either the subject of the intervention or the partner for change (Devaney, 2008). However, there is increasingly a general belief that the involvement of family members in decisions made about them is a more ethical and more effective way of proceeding. Furthermore, 
the involvement of family members in the planning of services is also seen as an effective means of reducing barriers to engagement and advancing social inclusion (Katz, La Placa, \& Hunter, 2007). Participation and inclusion are particularly seen as important in the provision of formal Family Support services where parents seek help voluntarily. Such practice has been defined in terms of a wider trend towards more openness and accountability on the part of the public services: a shift away from seeing people as passive beneficiaries of welfare to 'emphasise the capacity of family members to be creative, reflexive, active agents in shaping their lives and acting upon the outcomes of welfare policies' (Slettebø, 2013, pp. 578-580). This position supports an approach towards citizenship and participation where parents are active in the identification of their needs and issues (and in particular those of their children) and readily included in the plan for responding to this requirement for additional supports (Aarthun and Akerjordet, 2014).

However, such an approach is challenging with many barriers evident. Partnership with families has been described as an elusive concept especially in the context of rising inequality (Broadhurst and Holt, 2010). In the UK recent research highlights large inequalities in child welfare intervention rates with children living in deprived areas much more likely to be involved in child protection processes or to be taken into State care than children living in more affluent neighbourhoods (Bywaters, Brady, Sparks, and Bos, 2014; Bywaters 2015). A small number of US studies have also highlighted a link between family income and involvement in child protection services (Cancian, Yang and Slack, 2013). The relationship between parents and professionals has been identified as asymmetric, because of the authority and power of the service providers in such contexts (Aarthun and Akerjordet, 2014). If practitioners aspire to support families in a way that promotes their civic engagement they must continually strive to address such inequality and engage with family members in a respectful, honest, and inclusive manner.

The concepts of Prevention and Early Intervention are also core aspects of a Family Support orientation. They refer to the need to prevent difficulties and delays occurring in the first place but also intervening early where they are difficulties with the aim of preventing such issues becoming more serious and more entrenched. The focus, therefore includes working with children at an early stage in their life (that is, during their formative years) and also early in the genesis of a difficulty, that is providing a supportive response at any age as soon as issues manifest (Devaney, 2017). Dunst defined early intervention as 'the provision of support and resources to families of young children from members of informal and formal social support networks, that both directly and indirectly influence child, parent and family functioning' (2000, p.99). This definition highlights the need of a holistic approach including the child as the centre but also looking at their families, communities and environments as potential providers of support and provision of their needs; as well as the prevention of these needs in the first place.

Prevention and early intervention approaches have been shown to achieve much 
better outcomes than later interventions (Harvey, 2014). Early developmental prevention programs that are well designed and carefully implement have a positive impact on the child and the family, minimizing the negative effect on future health, educational, behavioural and criminality. Dekovic et al (2011) stated that early prevention programs can place children in positive developmental trajectories that can last into adulthood. Costly education, health and mental health problems have been linked to children and families lacking sufficient and suitable information, advice and support services early in life. Research also indicates that parenting (and poor parenting in particular) is a public health issue and that inadequate parenting practices have significant negative long term impact on children's behaviour (see Canavan, Devaney, McGregor and Shaw, 2019).

However, the research also highlights wider considerations. Prevention and early intervention outcomes are also impacted by the age of the children entering the services and the length of time in receipt of a service with those that have been in the services for longer the ones who report higher family outcomes (Raspa et al, 2010; Correia and Da Silva, 2013). Considering child protection issues specifically, a 'balancing act' between prevention and the wider commitment to safeguarding the well-being of children and young people may be required (Devaney and McGregor, 2017).

\section{Strengths-based practice}

A strengths-based perspective is also considered a cornerstone of practice in Family Support. A strengths-based approach refers to a philosophy of practice that builds on family members' competencies, supports families to make decisions for themselves, and focuses on enhancing the strengths of families, including cultural strengths, rather than fixing deficits. Services delivered in a manner consistent with this philosophy are thought to be more effective and empowering to families and lead to better long-term outcomes. Smith and Davis (2010) describe how a strengths based approach advocates choice, participation, anti-discrimination and timeliness and employs approaches that put peoples own solutions at the centre of service provision. In the UK, the 'Think Family' Report (2008), which aimed to provide a comprehensive support package to children and parents in 'families at risk', also advocated that services should start with families' strengths. This Report recommends that practitioners work with families, supporting them to build up their aspirations and capabilities, so they can take responsibility for their own lives and support each other in the present and in the future (p.8). Recognising that such an approach cannot take place in a vacuum, a system wide approach is suggested, with recognition that particular skills are needed by practitioners to confidently work with families in this way (pp.11-13). 


\section{Relationship based practice}

A persistent challenge for child welfare practitioners internationally has been developing meaningful relationships with family members (Cameron et al, 2013). The importance of valuing human relationships is a very basic belief and underpinning premise in Family Support. The relationship between the family members and practitioners has long been considered the 'bedrock' of practice (Mason, 2012) with emphasis placed on its importance in practice (Ruch, 2009). A relationship is utilised as a platform for specific and more targeted work with children and families. The approach and style taken by individual workers is viewed as a particularly important and central aspect of Family Support in practice. The quality of this relationship is seen as crucial in determining the experience of the family with evidence that a positive impact can be achieved through a positive relationship demonstrated (Spratt and Callan, 2004; Broadhurst and Holt, 2009). Specifically the importance of a shared understanding of the needs of families and strong connection between this need and the goals set is likely to produce better outcomes (Spratt and Callan, 2004).

While it is argued that practitioners are heavily constrained by competing demands on their time it is also argued that creating positive helping relationships is central to improving outcomes in child welfare (Cameron et al, 2013). It is also noted that addressing a negative behaviour is more effective if there is an existing relationship between the practitioner and the family members. Intervening in difficult situations where the worker knows the family, and the community, is more likely to have an impact and effect some real change.

At an overall level and in sum, McGregor and Devaney (2019) have advocated strongly that, in a similar to manner to child protection, Family Support is also viewed as everyone's business. The closer we can get to ensuring that children and families, no matter what point they come into contact with 'the system' or 'the state', are responded to in a manner that promotes strengths, prevents difficulties escalating, and offers partnership working within a respectful and non-judgmental professional relationship the more likely we are to achieve the goal of reducing abuse and neglect and enhancing family well-being.

\section{A theoretical basis for Family Support}

It is not enough to base our day-to-day intervention with children, young people and parents on practice wisdom. Payne defines theory as 'a general set of ideas that describes and explains our knowledge of the work around us in an organized way $(2014$, p.5). Family Support is informed by a fusion of social science theories. These include Social Support theory, the theories of Social Capital and Social Ecology, Attachment and Resilience. A Social Justice perspective is also important. This collective has an effect of acknowledging that although, Family Support is not a theory per 
se that is not to say it is 'theory less' (Frost, Abbot and Race, 2015; Devaney and Dolan, 2017). Family Support essentially is underpinned by theories that help us understand and respond to complex human needs: theories which have a casual explanation but also inform practical responses.

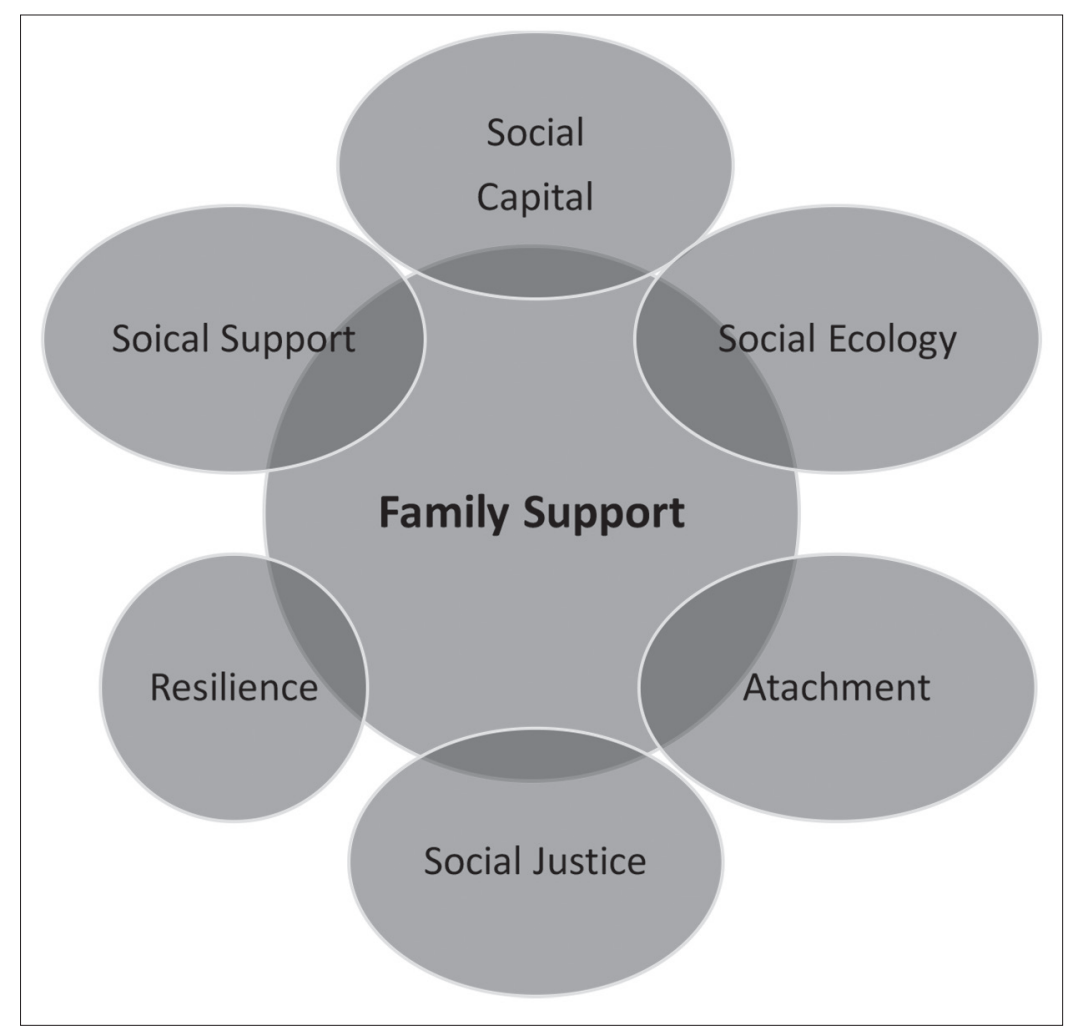

Figure 1. A theoretical basis for Family Support

Social Support theory provides a basis for many Family Support practices. In essence families typically avail of support that can be categorised as being practical, emotional or focused on providing information or advice. Social support is linked to the functional properties of a social network, which through mutual aid helps buffer parents from stresses by providing access to necessary resources (Finney at al., 2015). Highlighted as one of the core principles of Family Support, the building and strengthening of informal support networks, and the provision of supports and resources in a flexible, responsive and individualised manner to meet the changing needs of families, is a prerequisite of practice.

Recent literature in the area of child development reaffirms the suggestion that there is a strong link between the quality of the parent-child relationship and outcomes for children (Hintersanen, 2019). For the majority of children, the primary relationships 
formed within a family provide the platform from which children grow, develop and explore the world. Assured by the permanence and stability of their attachment to, and connection with their family members, children can grow and develop their full potential. The importance of a close continuous care-giving relationship for long term emotional development, and the impact of loss and separation in early childhood on well-being in later years is widely accepted and applied in research and literature on child development and adult-child relationships (Devaney, 2017). How children learn to develop such attachments influences their emotional and social development, including their perception on who they can trust and build positive relationships later in life. Applying attachment theory to the lifespan provides an understanding of why those who have suffered adverse relationships in the past go on to find relationships difficult in the future, with parents, peers, partners, children, neighbours and figures in authority (Howe et al, 1999). Although it is not inevitable that the children raised in adversity will, in their turn, become parents who raise their children in adversity, there is an increased risk that those who have suffered poor care giving will become poor care givers. Attachment theory also adds to the understanding regarding how the developmental wellbeing of children and adults can be recovered within good quality close relationships (Howe et al, 1999). An integral part of these relationships are the core functions performed within each one of them. This informal social support is provided by family members from adult to adult and crucially, from adult to child. The security and supports provided by family act as a protective factor, building children's resilience to cope with, adapt to, and survive life's challenges. Resilience is found to be a critical resource in coping with everyday challenges. While there are a number of definitions for resilience, Masten's (2001) assertion that resilience represents: 'good outcomes in spite of serious threats to adaptation or development' (p.228) is one which holds strong among a broad audience of policymakers, practitioners and academics, and has resonance for Family Support.

However, family life does not exist in isolation and consideration of the interconnected role of extended family, neighbours and communities as well as a variety of social institutions in family functioning is necessary (Devaney, 2017). Roubinov and Boyce (2017) argued that it is not sufficient to examine the construct of family and parenting at individual levels because family life is situated within and strongly influenced by the larger social ecology in which it unfolds. This social ecology within which children and families live, and the social capital which is accrued by the close ties which individual family members develop as part of these community-based relationships, is drawn on as a resource in good times and bad. Social capital refers to the social connections and networks between people which are based on principles of shared norms, trust and reciprocity. By emphasizing the value of social networks, social capital theory makes a critical connection between person-level dynamics and the broader societal arrangements (Fram, 2003). Whereas Castillo \& Fenzl-Crossman (2010) use social capital, social network and social 
support interchangeably, Dominguez \& Watkins (2003) subdivide social capital into social support, as the help one gets from close relationships to 'get by', to survive, on the one hand and social leverage, as the weaker connections one has with others to 'get ahead' in life, on the other. Both are seen as interdependent and originating from social networks or connections. Geens and Vandenbroek (2012) suggested that not only do all parents benefit from social support, but also local communities and the society as a whole. At a wider level, Family Support is also increasingly viewed as a social justice issue. As Stevenson (2009) notes, families have a right to be supported in their efforts and children have a right to be supported within their family unit. Social justice theory frames rights for all people, including young and old, within a model which implies an innate set of human rights which incorporate the key principle of 'recognition of any person' (Dolan, Zegarac $\&$ Arsi , 2020; Honneth and Fraser, 2003).

\section{Social structural models}

As noted previously, families are mediated by the social circumstances surrounding them such as income, employment, food, housing and health (Alonso, Ruiz, Sánchez and Oficialdegui, 2014). The family reality is not given in abstract, but is configured from the influences generated by the social context in which they find themselves. The social context, therefore, is an intrinsic part of family reality, which must be addressed in order to develop family support theory and practice.

Bearing this in mind, when supporting families, particularly those at risk and threatened due to poverty and discrimination, the intervention model must take into account the social structural, to help the family act against all the environmental barriers that could be hindering their well-being and limiting parental good practice. This applies not only from an assistance point of view, it must also be approached from a resilience (Manciaux, 2005; Cyrulnik, 2001) and critical (Giroux, 2001; Freire, 1968) perspective, in order to learn to overcome the different obstacles that emerge and, at the same time, to modify those of the systemic ordering that limits them. The intervention, in this sense, must focus its attention on stimulating the social intelligence of the family and, at the same time, help it to establish a new configuration of its circumstances, which will facilitate its well-being.

As indicated, exploiting protective factors often helps to establish such a new configuration. Protective factors are the opportunities that can and must be taken if the family situation is to improve.

The theory of human needs helps to understand how social circumstances (which are largely distilled from the social structure) can become factors of one kind or another. A review of this theory is presented below to explain how these needs can have an impact on the life of a family.

Throughout history there have been several researchers who have tried to identify 
the basic needs of every human being (Alderfer, 1972; López, 2008). Probably the framework Maslow presented (in the mid-twentieth century) is the most popular to date. This author understood that all people had common minimum needs. According to Maslow, these needs are organized in a hierarchical and pyramidal manner. In the lowest substrata are the most essential needs and in the highest those that contribute to full social and human development.

Maslow structured his approach that way because he understood that the subject is an integrated human being that when it has a need, that need occupies him/her and dominates him/her. Needs become, therefore, 'active determinants or organizers of behavior' (Maslow, 1975, p.89), since they try to put at their service all the potentialities of the person to strive to satisfy the need that at that moment captures all their attention. In that sense, if a parent knows that their children are hungry, they will try their best to provide them with food. And that until that priority need is satisfied, other needs cannot be focussed on.

These needs are then presented in the (ascending) order proposed by Maslow:

1. The physiological needs are located at the base. 'The human being that lacked everything, would tend to satisfy the physiological needs before the others' (Ibid., p.86).

2. In the second step is the security needs. Whose main demand is to be out of danger, threat or risk.

3. Next is the affective and social needs. They revolve around the need for affiliation, belonging, feeling part of a human group.

4. Then there is the needs of self-esteem and recognition. It is not just a question of being in the world, but of existence having some social value.

5. At the top of the pyramid the needs for self-fulfilment are established, which each person will seek to satisfy in a unique way.

These five categories are divided into two levels (lower and higher): the most basic (survival) needs will be those of the lower level, comprising the first three; and those of the upper (emancipation) level, comprising the last two:

Maslow differentiates between lower level needs and upper level needs. The former are fundamental for the individual and determine a clear control over their behavior when they are not satisfied. Once the basic necessities of subsistence have been satisfied, one enters the social necessities of self-esteem and belonging to a group. After the satisfaction of the latter, it will be in a position to cover specific intellectual and personal self-fulfilment (Sarramona, 2008, p.114).

This theory has been criticised over time, primarily with respect to the hierarchisation and the activation of the different needs. The classification, although it can be articulated using other categories, is helpful enabling a focus on social 
structural needs. Here we are particularly interested in how survival needs (at a lower level) condition the development of families. If families are to be concerned with day-to-day survival, they must be attentive to satisfying that which affects their most basic integrity, it will be difficult for them to carry out complex parental work in order to pursue the full development of the new generations. If, on the other hand, minimum needs were met, families could address issues related to the emancipation of their descendants.

Consequently, from a socio-structural, resilience and critical perspective, policies must be devised and mechanisms generated from all elements of the social fabric: economic, labour, educational, social, health and cultural, that make a minimum quality of life possible for all families. Society can develop in order to move towards a state of effective well-being that guarantees standards of living that allow families to take care of the upbringing and education of their children, seeking their full development.

\section{Relational and psychological models}

The previous section of this article has explored the role and relevance of social structural theories to understanding the challenges facing children, young people and their families in the contemporary world. In this section we move on to explore theory at the household, or inter-personal level, which practitioners may feel is more relevant to their everyday practice. We identify these theories as psycho-social.

One manifestation of psycho-social explanation relevant to family support is what is often referred to the 'toxic trio' of factors which are often found in child protection cases - the overlap of domestic abuse, mental ill-health and substance abuse. We argue that these factors are related to the wider social structural issues which have been discussed above: but social structural factors, whilst driven, by wider determinants, manifest themselves in unique formulations in particular households and in the personal lives of individuals. Social structural theory struggles to explain why one household may face some of the toxic trio issues, whilst another in a similar social structural position may not. For this we need to utilise more micro, or psycho-social, theories.

The widely utilised Hardiker model (Hardiker, Exton and Barker, 1991) is useful here in referring to the secondary and tertiary levels that family support comes into play. The secondary level is the emergence of social problems which many families may experience: isolation, marginalisation, discrimination, problems in parenting and financial problems being amongst these. These situations may be responsive to supportive approaches based in home visiting or increased community involvement perhaps. The tertiary level refers to more acute or severe problems - perhaps including child protection issues or substance abuse. Professional involvement may 
be required here if the family are supported in raising their children effectively and safely (Shannon, 2019).

One of the strengths - or arguably the weaknesses - of family support is that it offers a wide-range of diverse programmes and tools to support families that face the adversity outlined above. Family support is ultimately an optimistic approach - it believes that situations and change and improve. This can be delivered at the household level through relationship-based practice which is examined below (Frost, Abbott and Race, 2015).

As we have argued earlier relationship-based practice lies at the heart of family support practice: practitioners providing family support see the relationship as a vehicle for support and change (Herrera \& De-Oña, 2016). In family support this is based on working with (not doing to) families, drawing on theories of strengthbased and restorative practice. These approaches mean that agendas for change are devised alongside families and form of agreed, joint programmes of work (Canavan, Pinkerton and Dolan, 2016). An example is outlined in some detail below.

If a family identify a fifteen-year-old boy's behaviour as problematic-being hostile, missing school and not taking part in family life - a practitioner in a supportive role would speak to all family members - perhaps both individually and collectively. The practitioner will probably be aware of social structural explanations -around poverty, social class and gender, for example: however these may be of limited value in knowing how to actually work with the family. Utilising theories of family function, parenting and human relationships (what we have identified as psychosocial) the practitioner could reflect on how to work with the family. The practitioner may decide to meet with the family to discuss the situation and share perspectives. Often it would emerge at this stage that different family members have very different perspectives: for example, the mother may feel that the 15-year-old does not join in family occasions and the young person may feel that they are not invited to, or included in, such events. The worker may then be able to generate a shared agenda with the family: perhaps, in this case, to plan a family event and follow it with a family meeting to see how the event works out. Thus at a follow up meeting the worker may ask the individual family member show they felt about the event - again sharing perhaps diverse experiences, thus enabling the family to see interactions through the eyes of others. Empathy - understanding the world through the eyes of others - is a key approach here. It may be then that parents say that the fifteenyear-old never speaks but the young person feels they are not listened too, thus the worker would ask family members to reflect on these different perspectives and perhaps undertake a listening and feedback exercise. Thus, if this support works, it may help to improve family interaction in the short-term and perhaps in the longerterm. This fairly straightforward family support practice example illustrates how 'working with' and alongside families can help deliver positive change.

To further illustrate relationship-based practice, we refer to the work of the third sector organization 'Home-Start'. This organisation places relationship and 
community based support at the centre of its family support practice. The model involves a trained co-ordinator who recruits, trains and supports volunteers who visit families who have agreed to participate in the programme. The families and volunteers are matched and regular home visits take place. The agenda is set by the family - perhaps the parent feels isolated and wants someone to talk to, or perhaps they need someone to talk a challenge through with. The home visit is the central plank of the practice (Howard and Brooks Gunn, 2009). The frequency, timing and nature of the meetings is agreed through what has been identified as 'negotiated friendship'. Examples of the views of some families on their involvement with 'HomeStart', collected through a self-complete survey, are expressed below:

The visits made me feel confident and gave me good hints and tips, I appreciate the help I have received and the support as well.

Being at the group has made a difference to me and I really enjoy coming each week.

[The volunteer] donated us a double pram. It help me to go out to park in my own, my daughter loved her company and with chatting with someone. It helped me feel better and less stressed. Without your help wouldn't be able to get my teeth filling done. Thanks!

I cannot thank you enough for the wonderful support we have received. It has helped to get me back on my feet physically and emotionally. I hope one day that I can volunteer and support a family in the future as a way of showing my thanks.

This survey gives a voice to people supported by practitioners providing family support: such qualitative approaches allow us to assess the responses of families and see the value of family support through the eyes of its main protagonists.

\section{Towards an inclusive and integrated model}

Families face numerous and complex situations when it comes to raising their children. Parental work requires various kinds of support in a changing society that creates so many challenges. It is necessary to have a thorough knowledge of this work and the situations that circumscribe it in order to contribute to its support and development, which ultimately pursues the adequate development of children and young people (Rodrigo, Máiquez, Martín \& Rodríguez, 2015). This also contributes to the improvement of the community and social well-being in general.

Family support has a value base and ethical character based on social inclusion, the promotion of human dignity, human rights and the rights of children and young people. In order to shed some light on this, some of the basic aspects of the model 
outlined in the EFSN's founding document are highlighted below. Specifically, the holistic, ecological and comprehensive approach family support is based on is explained.

Families move in a complex (Morín, 2011) and inter-sectional reality (Konstantoni, Kustatscher \& Emejulu, 2017) where aspects of different nature that mediate their situation and, consequently, their parental work are inter-related. These aspects (including economic, labour, social, education and health) form a unique framework that influences them in an integrated manner.

The family reality should therefore not be addressed in a fragmented way or by losing sight of the whole. As far as possible, it must be understood from a holistic perspective: the singular aspects, the environmental aspects, the existing relations between them and the influences that they exert on each other (Bronfenbrenner, 1979). Therefore, a holistic view is required for each family reality. In this way, it is possible to make a complete and exhaustive assessment of each situation, at the same time that it is possible to understand the factors which influence in order to look for a solution.

The holistic gaze requires approaches that are neither linear nor confined within each system (von Bertalanffy, 1976). Therefore, it demands approaches that allow the construction of new ways of interacting between agents and linked actors, which makes co-production possible. A co-produced action that is inclusive, keeping in mind that working to a shared agenda will positively affect the development of parental work and be more sustainable in the long-term. This work does not consist of aligning actions or a sum of parts, but in the design and articulation of diverse contributions that are configuring a global collective project in a meaningful way for the family, since, in this way it can be more rooted, durable and useful for their development.

Networking is the work philosophy that is most coherent with this paradigm, since it is based on trans-disciplinarity. Partnership and coordination are indispensable strategic requirements in this type of work.

In an attempt to understand family support in a three-dimensional way, the model planned by the EFSN combines the following three axes: practice, research and policy.

The objective will be to contribute to the optimisation of the practices carried out by the agents who support families and/or to propose new ones: as a consequence, this should help to improve the parental work that these families carry out. The family occupies a central place in the three-dimensional pyramid formed by the three axes mentioned above and must actively participate in its development. In this way, family will be empowered, will have greater criteria and will be able to carry out its work with greater resources and autonomy.

The practitioners who intervene in this field have revealed themselves as key agents in this respect: contributing to training and professional development and, which is the purpose of this model, will have a positive impact on policy and practice.

On the other hand, as stated above, family support is a field that requires further 
epistemological development (Williams, 2010). Research is the mean through which it will be studied in its various aspects. From the rigorousness and the scientific method reality will be examined in an exhaustive way with the purpose of generating knowledge. Epistemic knowledge, but also instrumental knowledge, that will be used for the transformation and improvement of related practices and policies.

In this sense, the possibilities of participatory research methodologies are both coherent and stimulating, to the extent that they can incorporate (and it is beneficial to do so) all the agents and actors linked to the issue. In order to work in a participative way, it is essential to try to find tune between the languages used by all the participants (Herrera, Soler \& Mancila, 2019).

In relation to the political level, it is intended that the results of research can guide the different regulations related to this field at its different levels, to make them avant-garde and functional. This will make it possible to improve systems that are particularly connected with parental work (education, child protection, social and health services) and the welfare state in general.

All of this is presented internationally (at the European level) because it is understood that there are a series of points in common at the continental level that make possible to study the different practices, research (theories and knowledge) and policies (local and European). They can be confronted from a common framework that results in the improvement of family support and parental skills as a whole.

This triad aims to become a framework with a life of its own that gives shape to a synergetic process in which the potentialities of the different planes, agents and actors are exploited, with the purpose of carrying out the best possible family support. The challenge is to establish links between professionals, academics and policy makers to collaborate and generate capital and social fabric in that sense.

\section{Conclusion}

This paper has sought to provide a reflection on theoretical and conceptual frameworks that underpin formal family support as we understand it. It aims to inform and support cross-national collaboration across European countries, which until now had been a necessity, in an effort to advance Family Support as an international policy and practice orientation. Critically, it highlights the value of Family Support across in a variety of contexts with a focus on potential outcomes. An ecological, integrated and three-dimensional model combining the three areas of practice, research and policy is advocated as necessary in ensuring Family Support has an added value which ultimately impacts on those who need it most. This paper recognises that this debate is ongoing and that our thinking in this area continues to advance, inform and prompt ongoing debate in this regard. 


\section{References}

Aarthun, A. and Akerjordet, K. (2014) Parent participation in decision-making in health-care services for children: an integrative review', Journal of Nursing Management, 22(2), 177-191

Alderfer, C.P. (1972) Existence, relatedness, and growth: Human needs in organizational settings. New York: Free Press

Allen, G. (2011) Early Intervention: The Next Steps. London: The Stationery Office

Alonso, H., Ruiz, P., Sánchez, J. and Oficialdegui, R. (2014) Exclusión social, medio abierto e incorporación social en la Asociación Bizitegi: un modelo de intervención socioeducativa en programas de reinserción social desde la Pedagogía Social Comunitaria [Social exclusion, open environment and social incorporation in the Bizitegi Association: a model of socio-educational intervention in social reinsertion programmes from the Community Social Pedagogy], Educación Social. Revista de Intervención Socioeducativa, 57, 48-66

Bronfenbrenner, U. (1979) The ecology of human development: experiments by nature and design. Cambridge, MA: Harvard University Press

Broadhurst, K., and Holt, K. (2010) Partnership and the Limits of Procedure: Prospects for Relationships between Parents and Professionals under the New Public Law Outline, Child E Family Social Work, 15.1, 97-106

Bywaters, P. (2013) Inequalities in child welfare: Towards a new policy, research and action agenda, British Journal of Social Work, 45(1), 6-23

Bywaters, P., Brady, G., Sparks, T. and Bos, E. (2016) Child welfare inequalities: new evidence, further questions, Child and Family Social Work, 21, 369-380

Canavan, J., Pinkerton, J., and Dolan, P. (2016) Understanding Family Support: policy, practice and theory. London: Jessica Kingsley

Canavan, J., Devaney, C., McGregor, C., and Shaw, A. (2019) A good fit? Ireland's programme for Prevention, Partnership and Family Support as a public health approach to children protection. in Lonne, B.,Scott, D., Higgins, D. and Herrenkohl, T. (eds.) Re visioning public health approaches for protecting children. New York: Springer Publishers (pp. 397-413). https://doi.org/10.1007/978-3-030-05858-6_23

Cancian, M., Yang.,Mi-Youn, and Slack, K. S (2013) The Effect of Additional Child Support Income on the Risk of Child Maltreatment, Social Service Review 87:3, 417-437

Cameron, G., DeGeer, I., Hazineh, L., Frensch, K., Smit Quosai, T. and Freymond, N., (2013) The impacts of accessible service delivery on front-line helping relationships in child welfare, Child \& Family Social Work, 18(3), 253-263

Castillo, J.T. and Fenzl-Crossman, A., (2010) The relationship between non-marital fathers' social networks and social capital and father involvement, Child E Family Social Work, 15(1), 66-76

Cyrulnik, B. (2001) La maravilla del dolor: El sentido de la resiliencia [The wonder of pain: The sense of resilience]. Barcelona: Gránica

Deković, M., Slagt, M.I., Asscher, J.J., Boendermaker, L., Eichelsheim, V.I. and Prinzie, P. (2011) Effects of early prevention programs on adult criminal offending: A meta-analysis, Clinical psychology review, 31(4), 532-544 
Devaney, C. (2017) Promoting children's welfare through Family Support. in N. Frost and P. Dolan (eds) A Global Reader in Child Welfare. London: Routledge (pp. 99-109)

Devaney, C., \& McGregor, C. (2017) Child protection and family support practice in Ireland: A contribution to present debates from a historical perspective, Child and Family Social Work, 22( 3), 1- 9. https://doi.org/10.1111/cfs.12342

Devaney, C. and Dolan, P. (2017) Voice and meaning: the wisdom of Family Support veterans, Child \& Family Social Work, 22, 10-20

Devaney, J. (2008) Chronic Child Abuse and Domestic Violence: Children and Families with Long-term and Complex Needs, Child E Family Social Work. 13.4, 443-53

European Family Support Network (2020). European Family Support Network foundation document, $\quad \mathrm{c}$

Daly, M., Bruckhauf, Z., Byrne, J., Pecnik, N., Samms-Vaughan, M., Bray, R. and Margaria, A. (2015) Family and parenting support: Policy and provision in a global context. Florence: UNICEF

Dolan, P., Zegarac, N. AND Arsić, J. (2020) Family support as a right of the child. Social Work \& Social Sciences Review, 17, 2, 8-26

Dominguez, S. and Watkins, C. (2003) Creating networks for survival and mobility: Social capital among African-American and Latin-American low-income mothers, Social problems, 50(1), 111-135

Dunst, C.J. (2000) Revisiting 'Rethinking Early Intervention', Topics in Early Childhood Special Education, 20(2), pp.95-104. doi: 10.1177/027112140002000205

Easton, C., Gee, G., Durbin, B. and Teeman, D. (2011) Early intervention, using the CAF process, and its cost effectiveness. Findings from LARC 3. Slough: NFER

Elliott, M. and Scourfield, J. (2017) Identifying and Understanding Inequalities in Child Welfare Intervention Rates: Comparative studies in four UK countries. Oxford: The Nuffield Foundation

Featherstone, B., White, S., and Morris, K. (2014) Re-inventing Child Protection. Bristol: Policy Press

Firmin, C., Warrington, C and Pearce, J. (2016) Sexual Exploitation and Its Impact on Developing Sexualities and Sexual Relationships: The Need for Contextual Social Work Interventions, British Journal of Social Work, 46, 2318-2337

Freire, P. (1968) Pedagogía del oprimido [Pedagogy of the oppressed]. Madrid: Siglo veintiuno de España editores

Frost, N., Abbott, S. and Race, T. (2015) Family Support: prevention, early intervention and early help. Cambridge: Polity

Frost, N. and Dolan, P. (2012) The theoretical foundations of family support. in Davies, M. (ed.) Social work with children and families. Palgrave MacMillan: Basingstoke (pp. 40-52)

Frost, N., Abram, F. and Burgess, H. (2013a) Family Group Conferences: evidence, outcomes and future research, Child and Family Social Work, doi 10.1111/cfs 12047

Frost, N., Abram, F. and Burgess, H. (2013b) Family Group Conferences: context, process and way forward, Child and Family Social Work, doi 10.1111/cfs 12049

Geens, N. and Vandenbroeck, M. (2014) The (ab) sense of a concept of social support in parenting research: a social work perspective, Child E Family Social Work, 19(4), 491-500 
Giroux, H. (2001) Culture, educational policy and practice. Barcelona: Graó

Hardiker, P., Exton, K. and Barker, M. (1991) Policies and Practices in Preventive Child Care. Gower: Aldershot

Harvey, B. (2014) The Case for prevention and early intervention. Promoting Positive Outcomes for Children, Families and Communities. Dublin: Prevention and Early Intervention Network

Herrera, D., Soler, C., and Mancila, I. (2019) Interculturalidad crítica, teoría sociolingüística e igualdad de oportunidades. La extraordinaria historia de un menor infractor [Critical interculturality, sociolinguistic theory and equal opportunities. The extraordinary story of a young offender], Tendencias Pedagógicas, 33, 69-82. doi:10.15366/tp2018.32.006

Herrera, D., \& De-Oña, J.M. (2016) La importancia del ambiente de aprendizaje [The importance of the learning environment. Ecological education in a detention centre]. Revista Fuentes, 18 (1), 77-90. doi:10.12795/revistafuentes.2016.18.1.05

Fraser, N. and Honneth, A. (2003) Redistribution or recognition?: a political-philosophical exchange. London: Verso

Howard, K. and Brooks-Gunn, J. (2009) The Role of Home-Visiting Programs in Preventing Child Abuse and Neglect, Future of Children, 19 (2), 119-46

Howe, D., Brandon, M., Hining, D. and Schofield, G. (1999) Attachment Theory, Child Maltreatment and Family Support: a practice and assessment model. London: Macmillan

Jordan, L. (2012) The legal foundations of family support work. in Davies, M. (ed.) Social Work with Children \& Families. Hampshire: Palgrave Macmillan (pp. 26-39)

Katz, I., La Placa, V. and Hunter, S. (2007) Barriers to inclusion and successful engagement of parents in mainstream services. York: Joseph Rowntree Foundation

Konstantoni, K., Kustatscher, M., and Emejulu, A. (2017) Travelling with intersectionality across time, place and space. Children's Geographies, 15, 1-5

López Sánchez, F. (2008) Necesidades en la infancia y en la adolescencia. Respuesta familiar, escolar y social [Needs in childhood and adolescence. Family, school and social response]. Madrid: Pirámide

Mason, C. (2012) Social work the 'art of relationship': parents' perspectives on an intensive family support project, Child \& Family Social Work, 17(3), 368-377

Masten, A.S. (2001) Ordinary Magic: Resilience Processes in Development, American Psychologist, 56(3), 227-38

Maslow, A. (1975) Motivación y personalidad [Motivation and personality]. Barcelona: Sagitario

Manciaux, M. (2005) La resiliencia: resistirse y rehacerse [Resilience: resisting and rebuilding]. Barcelona: Gedisa

McGregor, C. and Devaney, C. (2019) Protective Support and Supportive Protection for Families 'in the Middle': Learning from the Irish Context, Child \& Family Social Work, vol. 25 (2), 277-285. DOI: https://doi.org/10.1111/cfs.12683

Morín, E. (2011) La vía para el futuro de la humanidad [The way for the future of humanity]. Barcelona: Paidós

Pinkerton, J., and Katz, I. (2003) Perspective through international comparison in the evaluation of Family Support. in I. Katz and J. Pinkerton (Eds.) Evaluating Family Support: Thinking Internationally, Thinking Critically. London: Wiley 
Raspa, M., Bailey, D.B., Olmsted, M.G., Nelson, R., Robinson, N., Simpson, M.E. Houts, R. (2010) Measuring Family Outcomes in Early Intervention: Findings from a Large-Scale Assessment, Exceptional Children, 76(4), 496-510. https://doi. org/10.1177/001440291007600407

Rodrigo, M.J., Máiquez, M.L., Martín, J.C. and Rodríguez, B. (2015) La parentalidad positiva desde la prevención y la promoción [Positive parenting from prevention and promotion]. in Rodrigo, M.J. (ed.), Manual práctico de parentalidad positiva [Practical Manual of Positive Parentality]. Madrid: Síntesis (pp. 25-43)

Roubinov, D.S. and Boyce, W.T. (2017) Parenting and SES: Relative values or enduring principles? Current Opinion in Psychology, 15, 162-167

Ruch, G. (2009) Identifying 'he critical' in a relationship-based model of reflection, Europeanjournal of Social Work, 12(3), 349-362

Sarramona, J. (2008) Teoría de la Educación. Reflexión y normativa pedagógica [Theory of Education. Reflection and pedagogical regulations]. Barcelona: Ariel

Shannon, M. (2019) Family Support for Social Care Practitioners. London: Red Globe Press

Slettebo, T. (2013) Partnership with Parents of Children in Care: A Study of Collective User Participation in Child Protection Services, British Journal of Social Work, 43(3), 579-595

Smith, M. and Davis, J.M. (2010) Construction of Family Support: Lessons from the Field, Administration, 58 (2), 69-82

Spratt, T. and Callan, J, (2004) Parents' views on social work interventions in child welfare cases, British Journal of Social Work, 34(2), 199-224

Stevenson, O. (2009) www.olivestevenson.com [Accessed 29th October 2019]

Think Family (2008) Think Family: Improving the life chances of families at risk. London: HMSO von Bertalanffy, L. (1976) Teoría General de los Sistemas [General Systems Theory]. Madrid: Fondo de Cultura Económica de España

Williams, N. (2010) Establishing the boundaries and building bridges. A literature review on ecological theory: implications for research into the refugee parenting experience, Journal of Child Health Care, Vol 14(1), 35-51. DOI: 10.1177/1367493509347116 